\title{
Practical Problems in the Customs Supervision on Cross-Border E-Commerce Goods and Its Solutions
}

\author{
Ting Liu \\ School of International Law \\ Shanghai University of Political Science and Law \\ Shanghai, China 201701
}

\author{
Zhenye Wang \\ School of Law \\ Shanghai University of Political Science and Law \\ Shanghai, China 201701
}

\begin{abstract}
With the rapid development of the Internet, the sales model of goods has changed. The prosperity of cross-border e-commerce has brought new challenges to traditional customs regulation. Under the impact of the new trade model such as cross-border e-commerce, China's customs' existing regulatory rules and tariff system have to be improved. There are conflicts between Law enforcement rights of customs and the interests of administrative counterparts. China makes efforts to construct service-oriented customs; customs enforcement of cross-border ecommerce needs more supervision. Therefore, improving the level of customs clearance services and rationally optimizing the customs taxation system are realistic solutions to problems brought about by cross-border e-commerce trade.
\end{abstract}

Keywords-customs supervision; cross-border e-commerce; administrative penalty power; intellectual property protection

\section{INTRODUCTION}

Cross-border e-commerce is a product of the Internet age. Compared with general trade, cross-border e-commerce trade is consumption-oriented and can better meet the diversified needs of consumers. The rapid development of cross-border ecommerce has promoted the continuous reform of customs supervision system. The entry and exit of general goods mainly follow the requirements of the Customs Law of the People's Republic of China (Customs Law), the Law of The People's Republic of China on Administrative Penalty (Administrative Penalty Law), the Regulations on the Administration of Inward and Outward Goods, and relevant documents issued by the General Administration of Customs. Chapter III of the Customs Law stipulates the customs control of the goods, from goods declaration to goods release, import and export license, inspection \& quarantine, etc. In 2012, the National Development and Reform Commission issued the Notice on Organizing and Launching E-Commerce Pilot Projects in National Model National E-Commerce Cities to explore, on a trial basis, supervision models suitable for cross-border import e-commerce, and later the customs proposed the customs supervision modes of "imports through overseas direct mail" and "imports through bond entry". From November to December 2018, relevant ministries of China issued four documents about cross-border e-commerce supervision policy, including the Notice on Improving the Supervision over Crossborder E-commerce Retail Imports, the Notice on Improving the Tax Policies on Cross-border E-commerce Retail Imports, the List of Retail Imports in Cross-border E-commerce (2018 version) and the Announcement on Matters Concerning the Supervision of Retail Imports and Exports in Cross-border Eecommerce. However, under the existing legal framework, there are still many practical problems in supervision over cross-border e-commerce by customs departments. Crossborder e-commerce trading mode mainly include B2B (business-to-business), ${ }^{1} \mathrm{~B} 2 \mathrm{C}$ (business-to-consumer) and $\mathrm{C} 2 \mathrm{C}$ (consumer-to-consumer). Among them, B2B is the transaction between two enterprises, which can still be classified as the traditional trading, and also accounts for the largest proportion of the total cross-border e-commerce transactions, and its customs clearance is also regulated as general goods. Through B2C mode, goods are sold directly to consumers; while through $\mathrm{C} 2 \mathrm{C}$ mode, goods are traded mostly through crossborder purchasing agent and cross-border online shopping. When goods are traded through $\mathrm{C} 2 \mathrm{C}$, due to its unique characteristics such as large quantity and small size, some merchants will divide the goods into small size and bulked ones to disguise them as nontrade personal goods for the purpose of evading customs supervision, which brings great pressure on traditional customs supervision over goods.

\section{Basic Regulatory POWER OF THE CUSTOMS ON CROSS-BORDER E-COMMERCE GOODS}

\section{A. Supervision Power of the Customs Over Cross-border E- commerce Goods}

The customs clearance of goods requires declaration and inspection by multiple departments, involving many supervising subjects that are decentralized. Now, as far as possible, the authorities related to the entry-exit customs clearance are unified into the customs, so as to reduce the declaration cost of counterparts. Such adjustment is because there are many similarities between the power of the entry-exit quarantine organ with that of the customs supervision organ: Their supervising objects are partially the same and both have the right to regulate the inward-outward goods; the scope of authority of the both is partly the same. The Regulation on the Implementation of Customs Administrative Punishment, and the Regulations for the Implementation of the Import and Export Commodity Inspection Law have stipulated the power

Ma Bianjing. Research on the Dilemma and Countermeasures of Customs Supervision over Cross-Border E-Commerce in the New Normal [J]. Economic Research Guide, 2016 (12). 
to punish the counterpart who fails to pass the inspection, so the integration of the two powers can improve law enforcement efficiency. However, after the institutional reform, the incongruity between the old and new legal systems brings many difficulties to law enforcement. For example, the Customs Law has no relevant provisions on the newly included "power of animal and plant quarantine", neither have relevant interpretation been issued so far. As a result, there will be a difficulty in application of law, for example, should the customs follow the Law of the People's Republic of China on the Entry and Exit Animal and Plant Quarantine or the Customs Law in enforcement. The institutional reform plan only transfer the power temporarily, and improving the system will require a lot of law revisions.

\section{B. Administrative Penalty Power of the Customs over Cross- border E-commerce Goods}

The power of administrative penalty of the customs over cross-border e-commerce goods is from the Customs Law, and on the basis of the Customs Law, the Regulation on the Implementation of Customs Administrative Punishment (Implementation Regulation) was formulated for the purpose of standardizing administrative penalties imposed by the customs and ensuring that the customs exercises its functions and powers in accordance with the law. The Implementation Regulation points out that the power of administrative penalty of the customs mainly applies to two circumstances: the smuggling acts not subject to criminal liabilities according to law; and the acts in violation of customs supervision provisions. In terms of customs enforcement, Article 3 of the Notice on Strictly Prohibiting the Illegal Transportation, Storage and Deal of Refined Oil jointly issued by relevant departments stipulates: "The customs, public security department and other relevant departments have the right to confiscate the products without going through legal and complete customs declaration procedures"2. This Article further confirms the administrative penalty power of the customs. The administrative penalty on cross-border e-commerce goods mainly falls into the first category. Most cross-border e-commerce businesses in B2C and $\mathrm{C} 2 \mathrm{C}$ modes go through the customs in small packages. The numerous and decentralized packages bring heavy workload to the customs, and such small packages are likely to have a smuggling risk. In reality, some logistics companies even collude with overseas students or overseas staff to falsely report the goods as personal luggage, and in this way, some goods of high price are packaged as other forms of articles and thus carried in secretly.

\section{PRACTICAL PROBLEMS IN CUSTOMS SUPERVISION ON CROSS-BORDER E-COMMERCE GOODS}

\section{A. Weakness in Customs Supervision on Cross-border E- commerce Goods}

Most cross-border e-commerce goods are delivered by the sellers themselves, which are mostly single pieces and heavily fragmented, and in a large number of scattered packages.

\footnotetext{
Refer to Article 3 of the Notice on Strictly Prohibiting the Illegal Transportation, Storage and Deal of Refined Oil
}

${ }^{3}$ Therefore, compared with traditional inward and outward goods, cross-border e-commerce goods are much harder to supervise.

1) Loopholes of supervision over imports through overseas direct mail and through bond entry: Article 24 of the Customs Law clearly states that the right holders of the inward and outward goods are the objects of customs supervision, and they are obligated to declare truthfully, and shall declare the goods within a specific time period and accept customs inspection, and the goods shall not be released unless passing the inspection. The supervision over cross-border e-commerce mainly lies in the judgment of commodity attribute and management of the commodity. Before the implementation of the new policy ${ }^{4}$ issued on April 8, 2016, the cross-border ecommerce imports were mainly through bond entry and overseas direct mail. Bond entry refers to first transporting the goods from abroad to a specific supervision area within China for storage, that is, preparing goods first and then selling them by order, which is commonly known as "bonded online shopping". After consumers place orders, the goods will be shipped directly from the bonded warehouse within China, and then go through customs clearance before release. The customs clearance requires strict consistency among the order, payment documents and logistics documents. This mode is usually adopted by large, certified and qualified cross-border e-commerce platforms, so small businesses failing to meet this requirement will choose other channels of entry, which is prone to causing many "desperate" illegal acts.

The "imports through overseas direct mail" mode means that consumers place orders directly via cross-border ecommerce platforms and the goods are delivered directly from overseas to China. Goods through this mode will go through customs clearance formalities in the mode of "checklist verification" just as traditional imports, and such goods are usually classified as "articles" and levied "personal postal articles tax". The declaration of imports through overseas direct mail has lower requirements than that of imports through bond entry. For purposes of regulating the supervision of the Customs over the express mail entering and exiting China, the Announcement No. 19 [2016] of the General Administration of Customs classify the inward express mails into three categories: Category A - documents and materials that are of no commercial value; Category B - personal articles; Category C goods worth 5,000 yuan or below. Most of customs clearance involves general luggage and postal articles. At present, the customs supervision mainly adopts on-site inspection of the goods after their arrival, and such supervision mode mainly relies on manual operation, and is characterized by imperfect information processing. In terms of taxes and dues, import taxes and duties on Category B express mails are the lowest, so it has become the first choice of cross-border e-commerce

Liu Bangfan, Ma Jinlian, Jia Lijie. Challenges and Countermeasures of Cross-Border e-Commerce to China's Customs Supervision [J]. Economig Research Cuide, 2018 (25).

Notice on Cross-Border E-Commerce Import Tax Policy jointly issued by the Ministry of Finance, the General Administration of Customs, and the State Administration of Taxation on April 8, 2016 
businesses. For instance, in reality, many articles that should be declared as "goods" are disguised as "articles". The current customs law system does not provide measures for the supervision over the two entry modes of cross-border ecommerce goods.

2) Goods entry-exit risk management easy to be ignored: According to the Announcement on Matters Concerning the Supervision of Retail Imports and Exports in Cross-Border Ecommerce -Article 26: paragraph 1 - the cross-border ecommerce enterprises shall transmit to the customs in real time the transaction data, open the permission of real-time logistics tracking etc. to facilitate the customs' risk management; paragraph 2- The cross-border e-commerce enterprises shall establish a quality and safety risk prevention and control mechanism to supervise abnormal transactions such as fictitious trading and secondary sales. In practice, the cross-border e-commerce subjects are usually not professional enough and have no experience in risk prevention during customs clearance, and one of the basic principles of customs supervision is to safeguard national rights and interests and ensure the security of foreign trade order. Loopholes in the supervision over inward and outward goods can sometimes be used by lawbreakers. However, but there are no specific regulations on customs risk prevention and control, so relevant it is necessary to develop risk prevention mechanisms as soon as possible.

3) Too much administrative discretion of the customs: According to Article 80 of the Legislation Law of the People's Republic of China, the discretion of China customs has a legal basis, which gives the departments with administrative functions directly under the State Council the right to formulate rules within the scope of their authority, so the General Administration of Customs has certain legislative power. Article 6 of the Customs Law and the Implementation Regulation stipulate that the customs has the right to punish those who violate the law, and the punitive measures shall depend on specific circumstances. In actual law enforcement, the customs often violate the administrative proportion principle when exercising its discretion. According to the administrative reconsideration and administrative litigation cases related to the customs in recent years, the proportion of cases in which the counterparts refuse to accept the customs punishment is increasing. According to the administrative proportion principle, the punishment imposed on a counterpart should be appropriate to the degree of its fault, but the customs in actual enforcement often does not consider whether to punish the counterpart in a more lenient way. ${ }^{5}$ Taking "false declaration" for example, due to the relative lack of professional knowledge, the counterpart sometimes will sometimes make a classification error, which is classified

Hu Ping, Wang Yan. The Real Fate of the Administrative Proportion Principle in the Administrative Law Enforcement of the Customs - From the Perspective of the Setting and Implementation of Customs Administrative Punishment [J]. Journal of Customs Enforcement, 2006 (4): 23-27. as false declaration by the customs, and the inconsistency between the declared duty-paying value and the price determined by the customs is also classified as false declaration. The Implementation Regulation stipulates different intensity of punishment to different law violation circumstances, but to improve the inspection speed, the customs often fails to subdivide the cases, and this may impose more severe penalties on the counterparts who are less illegal. Therefore, the customs shall achieve the regulatory purpose with the punitive measures that cause the least damage to the counterpart.

\section{B. Low Cost of Tax Evasion of Cross-border E-commerce Under the Current Customs Taxation System}

Cross-border e-commerce services are often provided based on online ordering and payment. Receipts for such transactions are often unavailable, and the exact transaction volume is hard for customs to know. Many businesses will take the risk of tax evasion to purchase goods through purchasing agents, and fail to declare and pay customs duties in accordance with the law. Goods that should be taxed as "goods" are packaged as "personal articles" and thus enter China at a low tax rate or even duty-free, resulting in great tax erosion. At present, China has not clearly stipulated the tax categories for cross-border ecommerce goods, and the sellers have not registered with the industry and commerce department, making it difficult for the customs and tax authorities to check the transaction details.

The $\mathrm{C} 2 \mathrm{C}$ mode of cross-border e-commerce mainly adopts the transaction mode of overseas purchasing through agent, and in this case, it is difficult for the customs to find out whether the goods purchased belong to goods or personal articles during customs clearance, which is also a big problem for the customs to prevent smuggling. ${ }^{6}$ For example, in 2017 a young purchasing agent named Zhao XX bought a lot of goods from Japan and Korea, carried them secretly when going through the customs and sold such smuggled goods through WeChat or Taobao Shop, although he knew clearly that goods purchased from abroad are subject to customs duties. In an airport security check, Zhao was found to carry smuggled goods. After further investigation, the customs found that Zhao had secretly bought goods from overseas frequently within half a year, with a total value of 2.8 million yuan and evaded customs duties of more than 800,000 yuan. Such purchasing from overseas is a major problem in customs supervision over goods. In addition, most cross-border e-commerce businesses are small and mediumsized enterprises with customs declaration personnel lacking in professionalism, so it is often to have errors in declaration information, which will also have an impact on customs duties. For instance, according to the information released by Xiamen customs in 2018, electronic and mechanical products are complicated, and it is necessary to analyze their real attribute from their functional principles, so they are often classified

\footnotetext{
6 Zhang Yanhong. Problems and Countermeasures of Personal Mail articles Supervision in Cross-border E-commerce [J]. Journal of the Staff and Worker's University, 2018 (3):52-56.
} 
wrongly in customs declaration, and the customs is also prone to make errors in applying the tariff nomenclature. ${ }^{7}$

\section{Lack of Intellectual Property Protection System}

Cross-border transactions are increasingly linked to intellectual property, and electronic products bought through cross-border e-commerce are likely to involve issues such as trademarks and patents. There are more and more infringement cases related to cross-border e-commerce goods seized by the customs throughout the country. For example, in April 2018, Changsha customs, according to the report of relevant personnel, seized and detained a batch of electric cars exported to Belarus by a Zhejiang enterprise via the China-Europe freight train. These goods did not have any brand or model, and were suspected of infringing the appearance design patent. This case was incorporated into the 2018 typical intellectual property protection cases of China customs ${ }^{8}$.

The Regulation of the People's Republic of China on the Customs Protection of Intellectual Property (Intellectual Property Protection Regulation) has specified the regulation functions of the customs: The customs shall, by administrative means, punish and stop infringement acts, maintain a fair foreign trade order and prevent the entry of infringing goods. However, in practice, the customs fails to implement the regulation strictly as stipulated. ${ }^{9}$ The Customs Law has clear provisions on the powers of the customs including inspection, taxation, anti-smuggling etc., but no provisions on intellectual property protection. In addition, the procedures for declaring intellectual property rights are complicated. At present, China customs protection procedures include two basic stages: filing and detaining suspected goods. The customs puts forward high requirements for the application for filing the intellectual property rights. For instance, Article 7 of the Intellectual Property Protection Regulation lists five necessary requirements for the application, including details of the manufacturer, exporter, import-export ports, etc. of the suspected infringing goods, which are difficult to obtain in a short time by the owner of the intellectual property rights. Besides, according to Article 17 of the Intellectual Property Protection Regulation, the holder of the intellectual property rights shall provide a detailed application for detention when discovering that the suspected goods are about to be imported or exported, and the applicant shall provide the customs with a guarantee not exceeding the equivalent value of the goods suspected of infringement. Legislators require applicants to meet such a high standard for application for filing intellectual property and for withholding suspected goods of infringement and to pay a certain amount of filing service fees and guarantees perhaps to save judicial resources, but for small commodity enterprises, these filing procedures undoubtedly

Xiamen customs administrative punishment case analysis - the product classification error [J/OL]. https://www.kuajingyan.com/article/707, 2019.4.15

8 Changsha customs seized 1404 export cross-border e-commerce articles of infringing of intellectual property rights [J/OL]. HTTP: / / http://news.sina.com.cn/c/2019-04-26/doc-ihvhiewr8415263.shtml 2019.4.28

Wang Zihan. Dilemma and Countermeasures of China's Intellectual Property Protection at the Customs [J]. Research on Intellectual Property Protection, Law and Economics, 2017 (03):71-78. increase the burden of applicants. As a result, due to small value of commodity and high cost of application, the holder of intellectual property rights may tolerate the infringement acts to avoid high declaration service cost, which is not conducive to intellectual property protection.

\section{PRoblem SOlution: DetaIled Rules AND SPECIAL CHANNELS}

The frequent disputes over cross-border e-commerce transactions not only pose challenges to legislation, but also raise higher requirements for customs supervision. ${ }^{10}$ On August 31, 2018, China passed the E-Commerce Law, which is first law specifically regulating e-commerce. As for the practical problems in customs supervision over cross-border ecommerce, it is not only necessary to improve the legislative guarantee, but also to further refine the rules and establish special channels for special supervision over cross-border ecommerce.

\section{A. Refining the Rules}

There should be legal norms in all aspects of customs clearance of goods, from the initial declaration of goods to their entry into the scope of customs control, customs inspection and release. Measures taken in each of the above steps shall be stipulated in detail by relevant laws and regulations. At present, the provisions of the Customs Law covers a wide scope but not concrete, and most customs regulations are "announcements" and "notices" jointly issued by the General Administration of Customs with other departments. There are few regulations on the procedure and mode of supervision, which gives customs enforcement great discretion. Therefore, it is necessary to detail the scope of supervision functions and powers of the customs as well as the supervision procedures at the legal level, so as to ensure there are relevant legal norms in all aspects, which is also the basic requirement of the principle of administration by law for law enforcement. Most customs laws are lower-level regulations, so it is necessary to improve the customs legal system by adopting administrative regulations and rules frequently used in practice through the NPC standing committee according to the actual needs, so as to stabilize the temporary laws and highlight the stability of the law. The customs legal system is complex, and many laws and regulations are issued by the General Administration of Customs and various departments, so they should strengthen the cooperation to timely straighten out the laws and revise the areas where the low-level laws exceed their powers to minimize conflicts in the application of laws. In the context of institutional reform, in addition to unifying customs power of supervision over goods, it is also necessary to straighten out the relationship between the old law and the new law, the general law and the special law, so as to facilitate each function department to use its strengths.

\footnotetext{
10 Yin Haoxuan, Wu Kexin. Analysis on the Influence of E-Commerce Law on Cross-Border E-Commerce in China [J]. Economic \& Trade, 2018
} (24):186. 


\section{B. Establishing Special Customs Clearance Channels for Cross-border E-commerce}

1) Simplifying clearance procedures: China has not yet established a management system specific for cross-border ecommerce. The existing customs clearance procedures are not well applicable to the management of cross-border ecommerce goods, so the current customs clearance mode should be reformed to become more professional. For example, on April 28, 2019, China started to set up "quick entry inspection channel for persons related to the Belt and Road". "The Belt \& Road" channels are set in 12 air ports including Beijing, Shanghai, Guangzhou etc., and in 6 land border ports including Manzhouli, Erenhot, Horgos etc. to facilitate Chinese and foreign personnel and vehicles implementing the "the Belt \& Road" related key projects, important cooperation, major programs, or participating "the Belt \& Road" related meetings and activities to quickly handle the border inspection procedures ${ }^{11}$, and such procedures are much faster than the normal entry process and greatly facilitate the parties involved. China can also try to establish exclusive channels for customs clearance of cross-border e-commerce, and all goods imported by overseas direct mail or bonded entry should go through the customs via such channels, which can make the customs supervision more targeted, and save a lot time than before.

2) Improving the single window system: The UN/CEFACT Proposal 33 released in 2005 defines the term "single window": Parties involved in foreign trade need to complete all declarations in a single "window" only for imports and exports. The parties involved in international trade are required to submit all the required documents and other legal documents through one platform, and after one centralized declaration, the supervision department will process the information and give feedback. The single window mode makes it more convenient for both sides of trade and regulatory authorities to provide and share trade regulation related information, thus improving the supervision efficiency and the customs clearance speed. At present, single-window customs clearance has been basically achieved nationwide, and the examination is carried out jointly by the General Administration of Customs, the Ministry of Commerce and other departments. However, in reality, characterized by large population and large amount of goods, China has to find out a single window mode with Chinese characteristics, it is advisable to establish a special department for customs clearance by the government, just as Switzerland and the Netherlands, which developed customs clearance system earlier and more advanced internationally, or to establish a public platform for government information processing as Singapore $^{12}$. The single window system also reflects the spirit of "service-oriented government". In the past, custom

11 China has set up "the Belt \& Road" channels at 18 ports to facilitate border inspection [J/OL]. http://finance.sina.com.cn/china/gncj/2019-0428/doc-ihvhiqax5478648.shtml, 2019.5.3

12 Zhu Mengming. China's Top Priority: Establishing a "Single Window" for International Trade. China’ s Foreign Trade [N], 2014 (07). clearance required declarations by multiple departments, and information communication among departments was often not smooth, which greatly reduced the clearance efficiency, and the "single window" system can make up for this deficiency. Therefore, this system should be improved constantly.

3) Using the customs administrative discretion reasonably: Customs enforcement shall strictly observe the basic principles of administrative law, identify the cases in strict accordance with the requirements stipulated in the Administrative Penalty Law and the Implementation Regulation, and give the counterpart ample opportunity to defend itself. If relevant measures should be taken against the counterpart in law enforcement, the method that causes the least damage to the counterpart must be chosen. When enforcing law, the customs shall consider whether it has punished the counterpart in a more lenient way and whether the punishment measure has been determined according to the degree of the counterpart's fault, so as to not only exercise the law enforcement power, but also not infringe upon the legal rights and interests of the counterpart. The counterpart believes that the customs can enforce the law according to law and thus declare the goods carefully for inspection. This is based on the applicant's reasonable trust in the public power of the state, and the reliance interest arising therefrom shall be protected. If the customs abuses its administrative discretion, it will violate the "trust protection principle".

To save the above problems, the author puts forward the following suggestions: (1) improve the normative legal documents of the customs as far as possible, timely straighten out relevant documents issued the General Administration of Customs and various departments, and remove the parts not applicable in the old laws, so that the customs will not be confronted with multiple conflicting laws and regulations in the supervision. (2) Collect typical cases of law enforcement, so that the customs can refer to specific standards and cases in law enforcement, which can reduce the abuse of discretion by law enforcement personnel to a certain extent. For example, in the supervision over cross-border e-commerce, with the increasingly higher informatization level, the information of Customs Supervision on Cross-Border E-Commerce Goods in the past shall be recorded into the database for the reference of later regulators. (3) Another important way is to improve the quality of customs law enforcement officers. Customs supervision requires high professionalism, so the customs personnel shall strengthen the study of basic professional knowledge. In addition, based on the requirements of "integration of power and responsibility" and "where there is power, there must be supervision", it is necessary to improve the internal supervision mechanism of the customs and have zero tolerance for the misconduct in office, as training highquality law enforcement officers is an important step to improve the national administrative system.

4) Strengthening customs risk management: It is difficult to trace the source of cross-border goods by relying on individual declaration only, especially the goods purchased by overseas online shopping, where there is often a contractual relationship between the buyer and the purchasing agent, as 
well as between the purchasing agent and the shipper. Sometimes, there are multiple resale relationships between buyers and shippers, making it difficult to determine the origin of goods, so cross-border e-commerce is often a hub for fakes. During the customs inspection, it is also difficult to determine whether the source of supply of the goods listed on the declaration form is true or not, and even if there is any abnormality, it is also difficult to trace the source of goods. According to the Announcement on Matters Concerning the Supervision of Retail Imports and Exports in Cross-Border Ecommerce - Article 9, Cross-border e-commerce platform enterprises and their domestic agents should be responsible for the authenticity of transactions, and shall provide detailed information of the identity of domestic buyers. This can facilitate the regulation of relevant cross-border traders of China, and help trace to consumers and thus can reduce trading risks. However, this regulation does not raise specific requirements for foreign shippers and sellers. To investigate the legal liabilities of both parties of cross-border commodities and solve relevant disputes, it is necessary to identify the both parties. Although it is not easy to know the details of overseas sellers, the regulation only requiring domestic consumers to be responsible for transactions remain to be improved, and the cross-border e-commerce platforms should also be required to be responsible for the authenticity of sellers' information.

In 2005, the Framework of Standards to Secure and Facilitate the Global Trade introduced a system conducive to achieving a win-win between the customs and enterprises, that is, "Authorized Economic Operator" (AEO) system, which aims to strengthen cooperation between the customs and enterprises to streamline the clearance procedures for eligible enterprises, such as enterprises without record of violating customs regulation. For the customs, the system can ensure both customs efficiency and safety; for enterprises, enterprises with AEO certification and qualification can enjoy more priority in customs clearance, and obtaining such certification is equivalent to improving the enterprise credit. This system requires close cooperation between enterprises and customs to ensure entry-exit security, which can greatly improve the clearance speed of goods. For enterprises, reducing transportation time is reducing costs. In addition, China should also actively promote the integration of other laws and regulations with the AEO system, and incorporate the substantial and procedural norms in the AEO system into laws. $^{13}$

\section{Further Improving the Customs Tax Collection and Management System}

1) Defining the standard of "reasonable self-use": The Customs Law was promulgated in 1987, and the current version is mainly a minor revision on the basis of the 2000 revision, and still separate goods and articles for supervision,

\footnotetext{
13 Announcement No. 131 of the General Administration of Customs - Announcement on Specifying the Specifications for Entering the "Authorized Economic Operator" (AEO) Codes [J/OL],

http://www.customs.gov.cn/customs/302249/302266/302269/2043578/index.h tml, 2019.4.25
}

without specific provisions on cross-border e-commerce. According to the Customs Law, to determine whether the commodities are for "reasonable self-use", it is mainly to see whether they are daily necessities for passengers' entry and exit, whether they are gifts for relatives and friends rather than goods brought into the country for sale or rent. When determining the "reasonable quantity", the customs usually estimates a reasonable quantity according to the purpose of exit and the length of stay abroad, but these standards change with people's living standards. Therefore, when exercising its discretion, the customs shall comply with the principle of "taking relevant factors into consideration" and examine goods in strict accordance with the examination standards. In reality, facing heavy workload, the customs sometimes will be arbitrary in law enforcement, and will even regard a counterpart as a suspect and take relevant measures against him/her only because the counterpart enters and leaves the country too frequently, which causes a lot of inconvenience to the passengers. Therefore, it is necessary to make detailed explanation of the concepts of "goods" and "articles" in the Customs Law, and to establish a clear standard of "reasonable self-use" to ensure fair and just law enforcement.

2) Detailing the schedule of dutiable value: From the latest Schedule of Dutiable Value listed in the Announcement No. 40 [2018] of the General Administration of Customs, it can be seen that although the customs has a detailed classification of goods, there are still many imperfections in determining the dutiable value of each type of goods. For example, the "watch" with tax code of 07010100, there is a large difference in value between name-list watches and ordinary watches, so the schedule of dutiable value does not provide a fixed dutiable price, but stipulates that the dutiable price shall be "separately determined" according to the value of the watch, and the tax rate is $25 \%$. This method increases the flexibility in law enforcement and is recommendable. However, clothing, cosmetics and other commodities that are also loved by most women are basically given a fixed dutiable value. In fact, brand values vary greatly. For example, for face creams of the same kind, Chanel is much more expensive than MUJI. Therefore, the schedule of dutiable value should be more flexible, and determining the dutiable value according to the actual value of commodities can avoid customs duties erosion to some extent.

3) Optimizing the customs valuation system through social intermediary agencies: To determine the dutiable value of inward and outward goods, the customs can learn from the accounting system and evaluate the goods passing through the customs through accounting firms. Accounting firms, by virtue of their strong professionalism, are more accurate and authoritative in identifying "reasonable self-use" and determining dutiable value than customs administrators. In this way, the customs delegate administrative power to social institutions through service outsourcing to fully use the strengths of all parties, which also well reflects the reform of "streamlining administration and delegating power, 
strengthening regulation, improving services". The professional review may also play a certain positive role in warning operators that go through the customs by a fluke. According to the tax systems of other countries in the world, strengthening the collection of tax-related third-party information can better urge taxpayers to abide by the tax law. For instance, the U.S. tax law requires the relevant departments to cooperate to provide tax source information to the Internal Revenue Service, and the Internal Revenue Code stipulates that relevant parties shall submit a variety of relevant information including "transactions with others" to the tax authorities. ${ }^{14}$ The French Code of Law Litigation stipulates how tax authorities can obtain tax-related information in detail, ${ }^{15}$ and even for private information, such as bank accounts, French law also allows tax authorities to supervise the taxpayers, regardless of violation of bank confidentiality principle. Although this can better supervise taxpayers, the French practice is suspected of excessive interference of public power in private power, which violates the proportionality principle stipulated by the administrative law.

To improve law enforcement, China customs can learn from the United States and France to strengthen the coordination and cooperation among relevant departments. Ecommerce operators, transaction and payment platforms and relevant supervision departments can upload transaction data to the network, and connect the payment platform directly with the customs, so that after each payment by buyers, the information on the payment platform and the transaction platform will be uploaded to the system automatically. In this way, the customs can directly find out the transaction details for each single piece of goods during the supervision, so as to prevent the false declaration and concealment by the sellers. However, in practice, it is necessary to protect the personal information of consumers and business operators and prevent such personal information from disclosure. The customs needs to strike an appropriate balance between the exercise of public power and the protection of private rights, otherwise it may violate basic principles of the administrative law.

\section{Strengthening Intellectual Property Protection}

Cross-border e-commerce concerns foreign interests, which makes it easy for such transactions to involve intellectual property of other countries. The trade friction between China and the United States in 2018 was mainly caused by the United States imposing unreasonable sanctions on Chinese enterprises under the pretext that China performs poor in intellectual property protection. All these have warned China of the importance of improving the international intellectual property protection system. China can give the customs the power of active enforcement. At the beginning of the establishment of

14 Pan Leichi, Ye Hua. Inspiration from the Comprehensive Governance Mechanism of Tax-Related Information in the United States on the Professional Management of Tax Sources in China [J]. Tax and Economic Research, 2012 (4):30-36.

15 Li Wanfu, Sun Hongmei: Research on Several Systems for the Revision of the < Tax Collection Administration Law > [M]. Beijing: Law Press, 2017:140-144. the intellectual property protection system, China adopted the method of mandatory filing, but in the process of amending the Intellectual Property Protection Regulation, considering that customs enforcement is the exercise of public power, intellectual property rights belong to private rights, and mandatory filing may interfere too much in private rights, the legislators changed mandatory filing to voluntary filing again. However, Chinese people generally have a low awareness of intellectual property protection, especially low-cost small commodity merchants, and the customs is unable to take the initiative to enforce the law on unrecorded intellectual property rights, so the customs may release lots of goods that infringe intellectual property rights. China customs may learn from foreign practices to give customs enforcement a certain degree of initiative power, but the customs shall be careful not to cross the line and shall not cause excessive damage to the counterpart. This can urge enterprises to improve their awareness of intellectual property protection, and is also conducive to promoting the progress of intellectual property protection in China.

\section{CONCLUSION}

China's customs cargo supervision system is gradually simplified. To encourage consumption, the government also provides a lot of convenience for the supervision over crossborder e-commerce, which generally reflects the principle of "high efficiency and convenience for people" and conforms to the current reform spirit of "streamlining administration and delegating power, strengthening regulation, improving services", but this is still far from the goal of building a service-oriented customs. According to the Plan for Restructuring the State Council adopted in 2018, the entry-exit inspection and quarantine regulatory responsibilities and teams of the General Administration of Quality Supervision, Inspection and Quarantine of the People's Republic of China are transferred to the General Administration of Customs. The adjustment of institutional functions can also reflect China's goal of building a service-oriented government. In the process of promoting the construction of service-oriented customs, it is necessary to further improve the cargo supervision system by perfecting the customs legal system, optimizing the supervision procedures and ensuring customs officers exercising law by law, etc., so as to better maintain the trade order.

\section{REFERENCES}

[1] Wang Mingyang. Administrative law of United States [M]. Beijing: China Legal Publishing House, 1995. (in Chinese)

[2] Luo Haocai. Administrative law [M]. Beijing: China University of Political Science and Law Press, 1999. (in Chinese)

[3] Yang Xangdong: Introduction to Administrative Law on Foreign Trade [M]. Beijing: China Legal Publishing House, 2012. (in Chinese)

[4] Zhang Hong. Customs Law [M]. Beijing: University of International Business and Economics Press, 2015. (in Chinese)

[5] Li Wanfu, Sun Hongmei: Research on Several Systems for the Revision of the < Tax Collection Administration Law > [M]. Beijing: Law Press, 2017. (in Chinese)

[6] Hu Ping, Wang Yan. The Real Fate of the Administrative Proportion Principle in the Administrative Law Enforcement of the Customs-- From the Perspective of the Setting and Implementation of Customs 
Administrative Punishment [J]. Journal of Customs Enforcement, 2006 (4). (in Chinese)

[7] Pan Leichi, Ye Hua. Inspiration From the Comprehensive Governance Mechanism of Tax-Related Information in the United States on the Professional Management of Tax Sources in China [J]. Tax and Economic Research, 2012 (4). (in Chinese)

[8] Guan Baoying. Question on the Basis of Administrative Discretion [J]. Science of Law, 2013 (3). (in Chinese)

[9] Zhu Mengming. China's Top Priority: Establishing a "Single Window" for International Trade. China's Foreign Trade [N], 2014 (07). (in Chinese)

[10] Cao Yanhua, Wei Xi. Reflection on the Basis of Administrative Discretion - Reflection Triggered by a Customs Administrative Lawsuit [J]. Customs Law Review, 2015 (00). (in Chinese)

[11] Ma Bianjing. Research on the Dilemma and Countermeasures of Customs Supervision Over Cross-Border E-Commerce in the New Normal [J]. Economic Research Guide, 2016 (12). (in Chinese)

[12] Wang Zihan. Dilemma and Countermeasures of China's Intellectual Property Protection at the Customs [J]. Research on Intellectual Property Protection, Law and Economics, 2017 (03). (in Chinese)

[13] Zhang Yanhong. Problems and Countermeasures of Personal Mail articles Supervision in Cross-border E-commerce [J]. Journal of the Staff and Worker's University, 2018 (3). (in Chinese)

[14] Liu Bangfan, Ma Jinlian, Jia Lijie. Challenges and Countermeasures of Cross-Border e-Commerce to China's Customs Supervision [J]. Economig Research Cuide, 2018 (25). (in Chinese)

[15] Yin Haoxuan, Wu Kexin. Analysis on the Influence of E-Commerce Law on Cross-Border E-Commerce in China [J]. Economic \& Trade, 2018 (24). (in Chinese)

[16] In 2018, China's imports and exports of goods exceeded 30 trillion yuan more than 30 trillion yuan, cross-border e-commerce market demand is expanding, and the trading environment is increasingly standardized. [J/OL]. http://www.chyxx.com/industry/201901/710425.html 2019.4.23. (in Chinese)

[17] Analysis on the main modes and competitive patterns of China's cross-

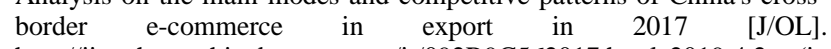
http://jingzheng.chinabaogao.com/it/092R9C562017.html 2019.4.2 . (in Chinese)

[18] China's cross-border e-commerce imports reached 862.4 billion yuan in the first half of 2017 [J/OL]. http://www.100ec.cn/detail, 6430069 HTML. 2019.4.15. (in Chinese)

[19] Xiamen customs administrative punishment case analysis - the product classification error [J/OL]. https://www.kuajingyan.com/article/707, 2019.4.15. (in Chinese)

[20] Changsha customs seized 1404 export cross-border e-commerce articles of infringing of intellectual property rights [J/OL]. HTTP: / / http://news.sina.com.cn/c/2019-04-26/doc-ihvhiewr8415263.shtml 2019.4.28. (in Chinese)

[21] China has set up "the Bel t\& Road" channels at 18 ports to facilitate border inspection [J/OL]. http://finance.sina.com.cn/china/gncj/2019-0428/doc-ihvhiqax5478648.shtml, 2019.5.3. (in Chinese)

[22] Announcement No. 131 of the General Administration of Customs--Announcement on Specifying the Specifications for Entering the "Authorized Economic Operator" (AEO) Codes [J/OL], http://www.customs.gov.cn/customs/302249/302266/302269/2043578/in dex.html, 2019.4.25. (in Chinese) 